\title{
Jenis dan Struktur Tema-Rema dalam Cerita Pendek "Nasehat untuk Anakku" Karya Motinggo Busye
}

\author{
Mujid Farihul Amin \\ Fakultas Ilmu Budaya, Universitas Diponegoro \\ mujidfib@gmail.com
}

\begin{abstract}
This study aims to determine what types of themes are contained in the short story "Advice for My Son" by Motinggo Busye and how the structure pattern of the teen theme is. The methodological framework consists of three strategic stages in the research, namely the data collection stage, the data analysis stage, and the data analysis result presentation stage. The results obtained from this study are that in the short story "Advice for My Son" by Motinggo Busye, there are topical / ideational themes including topical themes with markings and topical themes with markings, textual themes, and interpersonal themes. The structure of the themes contained in the short story "Advice for my Son" by Motinggo Busye is in accordance with the theme-rema theory, namely the theme is located at the beginning and the unit after the theme is rema.
\end{abstract}

Keywords: Theme; teenager; type; structure; short story.

\section{Intisari}

Penelitian ini bertujuan untuk mengetahui jenis tema apa saja yang terdapat dalam cerita pendek "Nasehat untuk Anakku" karya Motinggo Busye dan bagaimana pola struktur tema remanya. Kerangka metodologisnya melalui tiga tahapan strategis dalam penelitian, yaitu tahap pengumpulan data, tahap analisis data, dan tahap penyajian hasil analisis data. Hasil yang didapatkan dari penelitian ini adalah bahwa dalam cerita pendek "Nasehat untuk Anakku" karya Motinggo Busye terdapat tema topikal/ideasional meliputi tema topikal tanmarka dan tema topikal bermarka, tema tekstual, dan tema interpersonal. Struktur temarema yang terdapat dalam cerita pendek "Nasehat untuk Anakku" karya Motinggo Busye sesuai dengan teori tema-rema yaitu tema terletak di bagian awal dan satuan setelah tema adalah rema.

Kata kunci: Tema; rema; jenis; struktur; cerita pendek.

\section{Pendahuluan}

Manusia sebagai mahluk sosial tentu memerlukan interaksi dengan manusia lainnya. Sarana untuk melakukan interaksi dengan manusia lainnya menggunakan bahasa. Bahasa merupakan sistem lambang bunyi yang arbitrer yang dipergunakan untuk bekerja sama, berkomunikasi, dan mengidentifikasikan diri (Kentjono, 1982: 2). Sebagai sarana untuk berkomunikasi 
bahasa dapat menjadi sarana penyampaian pesan antara penulis dan pembaca. Seorang penulis tentu mempunyai tujuan ketika menyampaikan gagasan dan perasaan dalam sebuah cerita. Berikutnya, cerita itu tentu memiliki maksud yang menjadi tujuan dan harapan sampai kepada pembaca dan dapat persepsi yang sama antara yang dipikirkan penulis dengan yang dipikirkan pembaca setelah memahami cerita tersebut. Jadi, dalam hal ini bahasa mempunyai fungsi sebagai sarana untuk mengirimkan pesan yang berbentuk cerita. Objek dalam penelitian ini berupa cerita pendek yang berjudul "Nasehat untuk Anakku" karya Motinggo Busye. Sebagai sarana untuk menyampaikan pesan, bahasa yang digunakan dalam cerita pendek tersebut tentu saja tersusun dalam kata-kata, klausa-klausa, dan kalimat-kalimat yang akan dimaknai oleh para pembacanya.

Seorang pembaca yang baik memerlukan kecermatan dan ketelitian dalam memahamai makna sebuah cerita. Kreativitas dalam pengemasan makna sangat diperlukan ketika memahami makna sehingga tidak kesilapan makna sebenarnya yang akan diutarakan, supaya bisa ditemukan makna tersirat dan tersurat dalam suatu cerita. Supaya dapat memahami makna tersirat dan tersurat dalam suatu cerita, pasti dibutuhkan rangkaian katakata yang disusun dalam tata bahasa, dan kalimat (klausa) yang satu tidak merupakan hasil dari generasi kalimat (klausa) yang lain (Wiratno, 2018: 143). Jadi, penyusunan kata-kata menjadi klausa, klausa-klausa menjadi kalimat, kalimat-kalimat menjadi alinea sesuai dengan kaidah kebahasaan sangat penting untuk mempermudah pemaknaan.

Komunikasi yang dilakukan oleh dua belah pihak yaitu penulis dan pembaca, tentu saja harus disusun dalam bentuk ujaran-ujaran yang berwujud kalimat. Dalam penyampaian informasi, tentu saja terdapat bagian yang lebih ditekankan atau dipentingkan. Salah satu cara yang dapat digunakan untuk menekankan suatu bagian adalah dengan menempatkan bagian yang dipentingkan itu di bagian depan dalam sebuah konstruksi kalimat. Bagian yang diletakkan pada awal kalimat disebut Tema, sedangkan bagian akhir kalimat/bagian yang disusulkan adalah bagian yang melengkapi informasi yang telah disampaikan sebelumnya disebut Rema (Surono, 2014: 165). Menurut Saragih (2007:8), tema adalah awal pesan (the starting point of the message) dan rema adalah sisa pesan (the rest of the message) setelah tema.

Beberapa penelitian sebelumnya pernah dilakukan oleh peneliti lain dan relevan dengan penelitian ini. Penelitian tersebut sebagai berikut. Pertama, penelitian berbentuk tesis yang ditulis oleh Leonora (2007) bertajuk "Tema dan Pengembangannya pada Brosur Hotel Berbintang di Jawa Tengah dan D I Yogyakarta". Kedua, penelitian yang berwujud skripsi 
berjudul "Struktur Tema-Rema dalam Teks Abstrak Skripsi Mahasiswa Jurusan Sastra Indonesia Universitas Negeri Malang” yang disusun oleh Nugraha (2014). Ketiga, penelitian yang kemudian dituangkan dalam artikel berjudul"Struktur Tema-Rema dalam Teks Abstrak Berbahasa Indonesia" yang disusun oleh Nugraha (2017) dan dimuat dalam SIROK BASTRA, Vol. 5 No. 1, Juni 2017: 15-28. Keempat, penelitian yang dilakukan oleh Syartanti, dkk. (2020) dituangkan dalam artikel berjudul "Penggunaan Struktur Tema dan Rema dalam Cerita Rakyat Bali Pan Belog: Kajian Linguistik Sistemik Fungsional” yang dimuat dalam Prosiding Seminar Nasional Linguistik dan Sastra (SEMANTIKS). Sumber data ketiga penelitian di atas tentu saja beraneka ragam. Dengan keberagaman penggunaan sumber data dalam berbagai penelitian tersebut, ternyata masih belum ada yang memakai teks cerita pendek "Nasehat untuk Anakku" karya Motinggo Busye sebagai sumber data penelitian.

Oleh sebab itu, kajian dalam penelitian ini akan menitikberatkan pada pendeskripsian jenis-jenis tema yang terdapat dalam cerita pendek "Nasehat untuk Anakku" karya Motinggo Busye dan analisis struktur tema-rema dalam cerita pendek tersebut.

\section{Metode Penelitian}

Bila dilihat berdasarkan jenisnya, penelitian ini tergolong sebagai penelitian deskriptif kualitatif yang objek penelitian berwujud cerita pendek "Nasehat untuk Anakku" karya Motinggo Busye. Dalam pelaksanaannya, penelitian ini meliputi tiga pentahapan penting sebagaimana disampaikan oleh Sudaryanto (1993), yakni pengumpulan data, analisis data, serta penyajian hasil analisis.

Langkah yang peneliti lakukan pada tahap pemerolehan/pengumpulan data adalah peneliti memakai metode yaitu metode simak dan diteruskan dengan teknik catat. Implikasi praktis yang dijalankan adalah dengan cara menyimak cerita pendek "Nasehat untuk Anakku" karya Motinggo Busye dan diteruskan pencatatan data-data yang relevan dan dibutuhkan dalam riset ini. Kemudian, sesudah berbagai data yang dibutuhkan dapat dikumpulkan, berbagai data itu digolong-golongkan berdasarkan macam-macam tema dan pola struktur tema-remanya. Berbagai data yang telah digolong-golongkan tersebut, pada langkah berikutnya tinggal dianalisis. Berbagai data itu dilakukan analisis menggunakan dua jenis metode, yakni metode identitas dan metode normatif. Sesudah kegiatan pada tahap 
penganalisisan data selesai dilakukan, maka data sudah siap buat disajikan. Dalam penyajian data dilaksanakan dengan memakai metode penyajian informal, yakni suatu metode penyajian yang dilakukan dengan memakai kata-kata biasa tidak memakai simbol/lambang-lambang.

\section{Hasil dan Pembahasan}

Berikut struktur tema-rema yang terdapat dalam cerita pendek "Nasehat untuk Anakku" karya Motinggo Busye yang akan dijelaskan secara runtut berdasarkan jenis tema .

\section{Tema Topikal/Ideasional}

Dalam cerita pendek Nasehat untuk Anakku" karya Motinggo Busye terdapat banyak tema topikal baik tema topikal tanmarka maupun tema topikal bermarka. Analisis kedua tema topikal tersebut dapat dilihat pada data berikut.

\section{Tema Topikal Tanmarka}

Berdasarkan data yang ada, dalam cerita pendek Nasehat untuk Anakku" karya Motinggo Busye terdapat tema topikal yang berupa subjek yang disebut dengan tema topikal tanmarka 'unmarked topical theme' seperti yang terlihat pada data dalam tabel berikut.

Tabel 1 Kalimat dengan Satu Klausa yang mengandung Tema Topikal Tanmarka

\begin{tabular}{|c|c|}
\hline Tambang emas itu pun & belum dibuka. \\
\hline Subjek & Predikat \\
\hline Tema & Rema \\
\hline
\end{tabular}

Pada data tabel 1 di atas ditunjukkan bahwa kalimat dengan satu klausa dengan subjek yang terletak di bagian awal sebagai informasi yang penting dan diutamakan. Subjek yang merupakan analisis dari sudut fungsional kalau dilihat dari sudut tema-rema berfungsi sebagai tema topikal tanmarka. Hal itu karena klausa pada tabel 1 adalah klausa pendek yang disusun secara wajar. Klausa tersebut disebut klausa pendek yang disusun secara wajar karena kalau dilihat dari fungsi sintaksisnya terdiri atas dua unsur, yaitu subjek pada Tambang emas itu pun dan predikat pada belum dibuka. 
Tabel 2 Kalimat dengan Dua Klausa yang Mengandung Tema Topikal Tanmarka

\begin{tabular}{|c|c|c|c|c|c|c|c|}
\hline Ayah & Memaafkan & $\begin{array}{l}\text { hal } \\
\text { itu, }\end{array}$ & sebab & $\begin{array}{l}\text { pada } \\
\text { waktu } \\
\text { itu }\end{array}$ & $\begin{array}{l}\text { tiap- } \\
\text { tiap } \\
\text { orang }\end{array}$ & $\begin{array}{l}\text { haruslah } \\
\text { memiliki }\end{array}$ & $\begin{array}{l}\text { kesabaran dan maaf atas } \\
\text { segala kejadian yang } \\
\text { menimpa atau tidak } \\
\text { menimpa dirinya namun } \\
\text { menimpa kepala orang } \\
\text { lain. }\end{array}$ \\
\hline $\mathrm{S}$ & $\mathrm{P}$ & $\mathrm{O}$ & Konj & Ket & $\mathrm{S}$ & $\mathrm{P}$ & $\mathrm{O}$ \\
\hline & & & $\begin{array}{l}\text { Tema } \\
\text { Struk }\end{array}$ & Topik & & & \\
\hline Tema & \multicolumn{2}{|c|}{ Rema } & \multicolumn{2}{|c|}{ Tema } & \multicolumn{3}{|r|}{ Rema } \\
\hline \multicolumn{3}{|c|}{ Tema } & \multicolumn{5}{|c|}{ Rema } \\
\hline
\end{tabular}

Tabel 2 di atas menunjukkan bahwa kalimat dengan dua klausa dengan subjek terletak pada awal kalimat sebagai informasi yang penting dan ditekankan/diutamakan. Kata Ayah pada kalimat tabel 2 tersebut yang dari sudut fungsi sintaksisnya sebagai subjek, juga merupakan tema dari keseluruhan kalimat tersebut. Tema pada kalimat tabel 2 tersebut yang juga berfungsi sebagai subjek disebut tema tanmarka.

\section{Tema Topikal Bermarka}

Selain tema topikal tanmarka 'unmarked topical theme', dalam cerita pendek Nasehat untuk Anakku" karya Motinggo Busye terdapat tema topikal bermarka 'marked topical thema'. Disebut tema topikal bermarka 'marked topical thema' karena yang menjadi tema dalam kalimat tersebut tidak berfungsi sebagai subjek seperti yang terlihat pada data dalam tabel berikut.

Tabel 3 Kalimat dengan Dua Klausa yang Mengandung Tema Topikal Bermarkah

\begin{tabular}{|c|c|c|c|c|c|}
\hline Waktu itu & Ayahmu & sangat lapar sekali & Dan & hari & telah jam dua siang. \\
\hline Ket & $\mathrm{S}$ & $\mathrm{P}$ & Konj & $\mathrm{S}$ & $\mathrm{P}$ \\
\hline Tema & \multicolumn{2}{|c|}{ Rema } & Tema Struk & Topik & \\
\hline Tema & Rema & Tema & Rema \\
\hline Tema & \multicolumn{3}{c}{ Rema } \\
\hline
\end{tabular}


Tabel 3 menunjukkan bahwa bagian yang menjadi tema bukan merupakan subjek, tetapi bagian yang berfungsi sebagai keterangan. Karena yang menjadi tema bukan bagian yang berfungsi sebagai subjek, maka tema itu disebut tema topikal bermarka. Disebut tema topikal bermarka karena dalam bahasa Indonesia, elemen itu berpenanda atau bermarka nada akhir tinggi atau mendapat tekanan dan jeda yang lebih panjang daripada jeda antara subjek dan predikat. Adapun elemen-elemen di sebelah kiri tema disebut rema.

Berbeda dengan kalimat yang mengadung tema topikal bermarka pada tabel dua yang terdiri atas dua klausa, tabel 3 merupakan kalimat tunggal yaitu terdiri atas satu klausa dan di dalamnya terdapat tema topikal bermarka.

Tabel 4 Kalimat dengan Satu Klausa yang Mengandung Tema Topikal Bermarkah

\begin{tabular}{|c|c|c|}
\hline Kebetulan pada hari ini, & redaktur tempat ayah mengirimkan karangan & sangat baik hati. \\
\hline Ket & $\mathrm{S}$ & $\mathrm{P}$ \\
\hline Tema & \multicolumn{2}{|c|}{ Rema } \\
\hline
\end{tabular}

Kalimat pada tabel 4 merupakan kalimat tunggal yang terdiri dari satu klausa. Pada kalimat tersebut yang menjadi tema tidak berfungsi sebagai subjek sehingga disebut tema topikal bermarkah. Disebut tema topikal bermarka karena dalam bahasa Indonesia elemen itu berpenanda atau bermarka nada akhir tinggi atau mendapat tekanan dan jeda yang lebih panjang daripada jeda antara subjek dan predikat. Adapun elemen-elemen di sebelah kiri tema disebut rema.

\section{Tema Tekstual}

Dalam cerita pendek Nasehat untuk Anakku" karya Motinggo Busye juga terdapat tema tekstual. Tema tekstual tersebut dinyatakan dalam wujud konjungsi dan penanda wacana kontinuatif seperti tampak pada tabel data-tabel data berikut.

Tabel 5 Kalimat dengan Satu Klausa yang Mengandung Tema Tekstual Berwujud Konjungsi

\begin{tabular}{|c|c|c|c|l|}
\hline Tetapi & janganlah & kau & bercita-cita & $\begin{array}{l}\text { jadi seorang pengarang macam } \\
\text { aku ini. }\end{array}$ \\
\hline Konj & Fatis & S & Predikat & Pelengkap \\
\hline $\begin{array}{c}\text { Tema } \\
\text { Strk }\end{array}$ & Kont & Topik & \multicolumn{2}{|c|}{} \\
\hline
\end{tabular}




\begin{tabular}{|c|c|}
\hline Tema & Rema \\
\hline
\end{tabular}

Kalimat pada tabel 5 yang hanya terdiri atas satu klausa menunjukkan bahwa pada kalimat tersebut terdapat tema tekstual. Disebut tema tekstual karena kalimat pada tabel 5 tersebut, yang menjadi temanya berupa konjungsi yang terletak pada awal kalimat.

Tabel 6 Kalimat dengan Dua Klausa yang Mengandung Tema Tekstual Berwujud Konjungsi

\begin{tabular}{|c|c|c|c|l|c|c|c|c|}
\hline Tetapi & Aku & punya & usul: & bagaimana & kalau & kau & Berusaha & $\begin{array}{c}\text { untuk jadi insinyur } \\
\text { pertambangan saja? }\end{array}$ \\
\hline Konj & S & P & Pel & & Kon & S & P & Pel \\
\hline $\begin{array}{c}\text { Tema } \\
\text { Strk }\end{array}$ & Topik & & & & & & & \\
\hline \multicolumn{2}{|c|}{ Tema } & & & & & & & \\
\hline
\end{tabular}

Tabel 6 menunjukkan bahwa kalimat pada tabel itu terdiri dari dua klausa dan di dalam kalimat itu terdapat tema tekstual. Disebut tema tekstual karena kalimat pada tabel 6 tersebut, yang menjadi temanya berupa konjungsi yang terletak pada awal kalimat.

Tabel 7 Kalimat dengan Dua Klausa yang Mengandung Tema Tekstual Berwujud Konjungsi

\begin{tabular}{|c|c|l|l|l|l|}
\hline Dan & Karena & $\begin{array}{l}\text { ratapannya } \\
\text { itu, }\end{array}$ & $\begin{array}{l}\text { bis-bis, becak-becak yang ditarik } \\
\text { manusia dan mobil-mobil } \\
\text { pembesar pun }\end{array}$ & diharuskan & $\begin{array}{l}\text { berhenti lebih } \\
\text { dulu. }\end{array}$ \\
\hline \multicolumn{2}{|c|}{ Keterangan } & \multicolumn{2}{|c|}{ Subjek } & Predikat & Pelelengkap \\
\hline \multicolumn{2}{|c|}{ Tema } & \multicolumn{2}{|c|}{ Rema } \\
\hline
\end{tabular}

Tabel 7 di atas menunjukkan bahwa dalam kalimat tersebut tema tekstualnya berwujud konjungsi yang treletak di awal kalimat

Tabel 8 Kalimat dengan Dua Klausa yang Mengandung Tema Tekstual Berwujud Unsur Kontinuatif

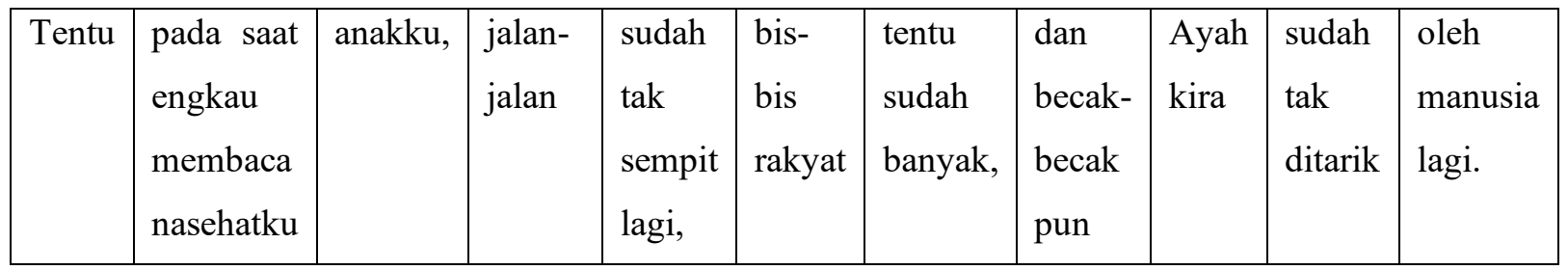




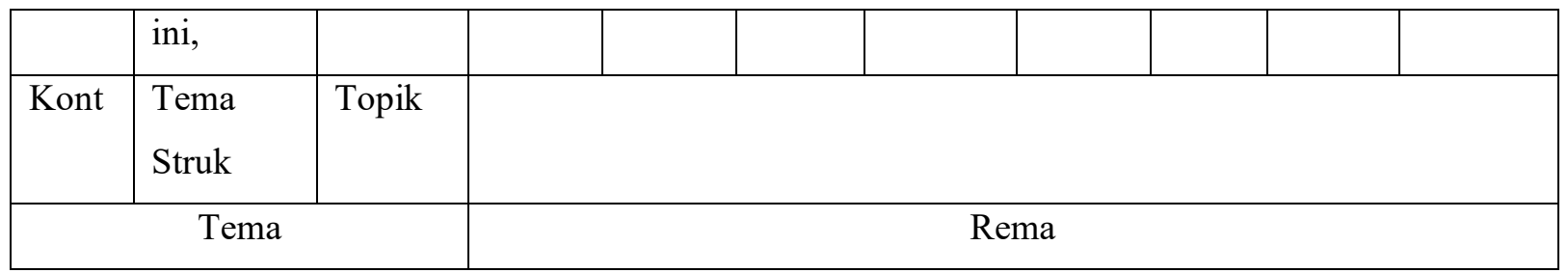

Tabel 8 di atas menunjukkan bahwa dalam sebuah kalimat yang terdiri atas dua klausa, tema tekstualnya bisa berupa unsur kontinuatif. Pada kalimat di tabel 7, tema tekstual tidak hanya dibangun oleh unsur kontinuatif saja, melainkan bersama-sama dengan tema struktural dan topik. Jadi, pembentuk tema pada kalimat tabel 7 adalah unsur kontinuatif, tema structural, dan topik.

\section{Tema Interpersonal}

Dalam cerita pendek "Nasehat untuk Anakku" karya Motinggo Busye juga terdapat tema interpersonal. Tema interpersonal tersebut dinyatakan dalam wujud modalitas, vokatif/kata sapaan. dan kata tanya seperti tampak pada tabel data-tabel data berikut.

Tabel 9 Kalimat dengan Empat Klausa yang mengandung Tema Interpersonal

\begin{tabular}{|c|c|c|}
\hline Mungkin & engkau & $\begin{array}{l}\text { pada saat itu telah menjadi salah seorang calon penerbang ruang } \\
\text { angkasa, dan tambang emas telah digali orang di Lampung, dan di } \\
\text { dusun-dusun telah berkilauan lampu-lampu listrik dari neon, dan } \\
\text { Irian Barat telah menjadi hak milik Indonesia. }\end{array}$ \\
\hline Modalitas & & \\
\hline Interpers & Topik & Rema \\
\hline \multicolumn{2}{|c|}{ Tema } & \\
\hline
\end{tabular}

Kalimat pada tabel 9 yang terdiri atas empat klausa menunjukkan bahwa di dalam kalimat tersebut terdapat tema interpersonal pada klausa pertama berupa modalitas. Modalitas adalah konstituen kalimat yang mengungkapkan sikap pembicara. Pada data tersebut, sikap pembicara ditunjukkan dengan penggunaan modalitas mungkin yang menerangkan seluruh satuan yang berada di belakang modalitas tersebut.

Dalam cerita pendek "Nasehat untuk Anakku" karya Motinggo Busye, terdapat pula tema interpersonal yang direalisasikan dalam wujud kalimat tanya seperti pada kalimatkalimat di tabel-tabel berikut. 
Tabel 10 Kalimat dengan Satu Klausa yang Mengandung Tema Interpersonal

\begin{tabular}{|c|c|}
\hline "apalagi & yang akan kau beli?" \\
\hline $\mathrm{P}$ & $\mathrm{S}$ \\
\hline Tema & Rema \\
\hline
\end{tabular}

Tabel 10 di atas menunjukkan bahwa dalam kalimat yang terdiri atas satu klausa tersebut, tema interpersonal ditandai oleh pemarkah tanya berupa kata tanya apalagi.

Tabel 11 Kalimat dengan Satu Klausa yang Mengandung Tema Interpersonal

\begin{tabular}{|c|c|}
\hline " kapan & bukumu terbit.?" \\
\hline $\mathrm{P}$ & $\mathrm{S}$ \\
\hline Tema & Rema \\
\hline
\end{tabular}

Tabel 11 di atas menunjukkan bahwa dalam kalimat yang terdiri atas satu klausa tersebut, tema interpersonal ditandai oleh pemarkah tanya berupa kata tanya kapan.

Tabel 12 Kalimat dengan Satu Klausa yang Mengandung Tema Interpersonal

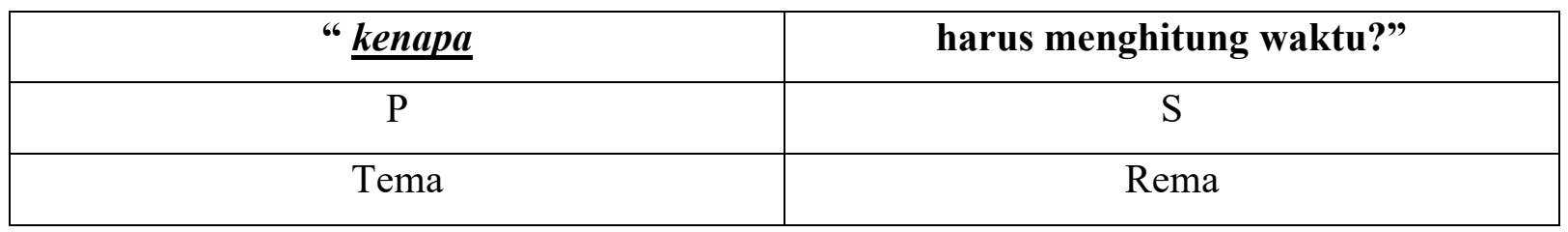

Tabel 12 di atas menunjukkan bahwa dalam kalimat yang terdiri atas satu klausa tersebut, tema interpersonal ditandai oleh pemarkah tanya berupa kata tanya kenapa.

\section{Simpulan}

Berdasarkan hasil dan pembahasan struktur tema dan rema cerita pendek "Nasehat untuk Anakku" karya Motinggo Busye pada bagian hasil dan pembahasan, maka bisa diambil simpulan bahwa dalam cerita pendek tersebut terdapat semua macam/jenis tema. Jenis/macam tema yang paling dominan adalah tema topikal tanmarka karena sebagian besar dimulai dengan nomina, frasa nominal, atau klausa atributif. Dalam cerita pendek tersebut juga terdapat tema topikal tanmarka, tema topical bermakna, tema tekstual, dan tema 
interpersonal. Struktur pola seperti pada umunya, yaitu tema terletak di bagian awal kalimat, baru menyusul di belakangnya adalah rema.

\section{Daftar Pustaka}

Nugraha, A. Danang Satria. 2014. "Struktur Tema-Rema dalam Teks Abstrak Skripsi Mahasiswa Jurusan Sastra Indonesia Universitas Negeri Malang”. Skripsi. Jurusan Sastra Indonesia - Fakultas Sastra UM. 2017. "Struktur Tema-Rema dalam Teks Abstrak Berbahasa Indonesia". SIROK BASTRA, Vol. 5 No. 1, Juni 2017: 15-28.

Kentjono, Djoko. 1982. Dasar-dasar Linguistik Umum. Jakarta: UI Press.

Leonra, Andini. 2007. "Tema dan Pengembangannya pada Brosur Hotel Berbintang di Jawa Tengah dan D.I. Yogyakarta". Tesis. Program Pascasarjana Universitas Diponegoro.

Saragih, Amrin. 2007. Fungsi Tekstual dalam Wacana, Panduan Menulis Rema dan Tema. Medan: Balai Bahasa Medan.

Sudaryanto. 1993. Metode dan Aneka Teknik Analisis Bahasa: Pengantar Penelitian Wahana Kebudayaan Secara Linguistis. Yogyakarta: Duta Wacana University Press.

Surono. 2014. Analisis Frasa-Kalimat Bahasa Indonesia. Semarang:Gigih Pustaka Mandiri.

Syartanti, Nadya Inda dkk. 2020. "Penggunaan Struktur Tema dan Rema dalam Cerita Rakyat Bali Pan Belog: Kajian Linguistik Sistemik Fungsional". Prosiding Seminar Nasional Linguistik dan Sastra (SEMANTIKS) 2020 ISBN: 978-62394874-0-9 "Dokumentasi Bahasa dan Kebijakan Bahasa" https://jurnal.uns.ac.id/prosidingsemantiks.

Wiratno, Tri. (2018). Pengantar Ringkas Lingusitik Sistemik Fungsional. Yogyakarta: Pustaka Pelajar. 